\title{
ARAHAN DAN STRATEGI PENGEMBANGAN PERIKANAN WILAYAH PESISIR KABUPATEN PADANG PARIAMAN
}

\author{
M. Rifqi*), Dietriech G. Bengen ${ }^{* *}$ dan Victor P. H. Nikijuluw***)
}

\begin{abstract}
ABSTRAK
Kabupaten Padang Pariaman merupakan salah satu daerah kabupaten di Propinsi Sumatera Barat yang memiliki wilayah pesisir dan laut. Melihat potensi yang ada, perubahan orientasi pembangunan dari pembangunan yang berbasis sumberdaya daratan (land based resources) kepada pembangunan yang berbasis sumberdaya kelautan dan perikanan (marine and fisheries based resources) memungkinkan di Kabupaten Padang Pariaman. Pada pelaksanaannya Kabupaten Padang Pariaman harus mampu menghasilkan suatu strategi dan arahan pengembangan perikanan wilayah pesisir yang sesuai dengan kapasitas daya dukung sumberdaya yang ada, mempunyai daya saing, berkelanjutan dan berwawasan lingkungan, serta dapat segera diimplementasikan. Kegiatan ekonomi masyarakat yang telah berkembang di wilayah pesisir Kabupaten Padang Pariaman adalah kegiatan perikanan tangkap dan kegiatan pengolahan hasil perikanan. Disamping itu wilayah pesisir Kabupaten Padang Pariaman juga mempunyai potensi lahan budidaya yang belum termanfaatkan. Untuk dapat menyusun strategi dan arahan pengembangan perikanan wilayah pesisir Kabupaten Padang Pariaman dilakukan analisis faktor internal dan eksternal dalam menentukan keunggulan komparatif dan keunggulan kompetitif kegiatan perikanan wilayah pesisir Kabupaten Padang Pariaman, yang selanjutnya dengan analisis SWOT dihasilkan strategi dan arahannya
\end{abstract}

ABSTRACT: Guidelines and strategy for the development of coastal fisheries in the district of Padang Pariaman. By: M. Rifqi, Dietriech G. Bengen and Victor P. H. Nikijuluw.

Padang Pariaman district is one of district in West Sumatra of which hearing a coastal and marine resource. With respect to its resource potential, re-activity the region development basis from land-based to marine and fisheries based was possible to be conducted. Operationality, the region should be able to develop such a guidelines and strategy for coastal fisheries development by which in line with the resources carrying copied, competitiveness, suistainable and ecological friendly providing that there can be implemented as early as possible. Economic activity which is already developed in coastal areas of Padang Pariaman includes fish capture and processing. Aquaculture potential is too far underdeveloped. This research was aimed at formulation of strategy and direction of coastal fisheries development in Padang Pariaman, by means of analyzing both external and internal factor to determine comparation and competitive advantage a final formaly of the strategi of direction is considered based on SWOT analysis.

KEYWORDS: fisheries resources, Padang Pariaman District, internal and external, factor analysis, SWOT analysis

\section{PENDAHULUAN}

Pemberlakuan UU No. 22 tahun 1999 tentang Pemerintah Daerah dan UU No. 25 tahun 1999 tentang Perimbangan Keuangan Antara Pusat dan Daerah sangat mempengaruhi kondisi keuangan daerah Kabupaten Padang Pariaman. Sumber dana pembangunan untuk tahun $1999 / 2000$ yang berjumlah Rp. 28,549 milyar adalah dana bantuan khusus yaitu $47,42 \%$, dana bantuan umum $25,38 \%$ dan dana bantuan luar negeri $18,91 \%$, sedangkan yang bersumber dari pendapatan asli daerah (PAD) hanya $7,44 \%$ dan yang berasal dari sumber lainnya adalah
0,85 \% (Bappeda Padang Pariaman, 1999). Untuk itu Pemda Kabupaten Padang Pariaman harus mampu mencari sumber-sumber dana dari potensi daerah yang dapat dikembangkan. Dalam jangka pendek sumberdaya pesisir dan lautan yang dapat dikembangkan adalah sektor perikanan. Sumberdaya perikanan di Kabupaten Padang Pariaman terutama perikanan tangkap relatif besar dibandingkan sumberdaya pesisir dan laut lainnya (seperti: mineral dan bahan tambang, energi pasang surut, keindahan pantai, dll.). Selain itu, kegiatan ekonomi masyarakat yang memanfaatkan sumberdaya pesisir dan laut yang sudah berkembang adalah kegiatan perikanan

Staf Direktorat Jenderal Perikanan Budidaya, DKP

Fakultas Perikanan dan IImu Kelautan, Institut Pertanian Bogor

-) Staf Direktorat Jenderal Pengembangan Kapasitas Kelembagaan dan Pemasaran, DKP 
Perkembangan kegiatan perikanan di wilayah pesisir Kabupaten Padang Pariaman telah berjalan seiring dengan proses pembangunan, namun dibandingkan dengan sektor lain di kabupaten ini dan kegiatan perikanan daerah lain di Sumatera Barat, perkembangannya relatif lebih lambat. Kegiatan perikanan di wilayah pesisir Kabupaten Padang Pariaman diantaranya adalah perikanan tangkap, pengolahan dan pemasaran/distribusi hasil perikanan (Bappeda Padang Pariaman, 2001a).

Permasalahan perikanan tangkap di Kabupaten Padang Pariaman muncul dari faktor-faktor berikut: (1) rendahnya kemampuan armada perikanan (sebagian besar < $5 \mathrm{GT}$ ), (2) rendahnya tingkat pendidikan dan keterampilan masyarakat nelayan, (3) kurangnya fasilitas pelabuhan, dermaga, dan tempat pendaratan ikan, dan (4) kurangnya investasi dan perhatian pemerintah di bidang perikanan. $\mathrm{Hal}$ ini terlihat dari terbatasnya daya jelajah armada penangkap (sebagian besar di bawah 12 mil), rendahnya produktifitas dan efisiensi usaha penangkapan, adanya nelayan yang mendaratkan hasil tangkapannya di Kota Padang dan daerah lainnya karena memiliki sarana pelabuhan, dermaga, dan pendaratan ikan yang lebih baik.

Sedangkan permasalahan perikanan budidaya muncul dari faktor-faktor: (1) lahan yang tersedia relatif sedikit, (2) tingginya biaya investasi, dan (3) belum tersedianya teknologi budidaya di tingkat masyarakat. Sehingga sampai sekarang belum ada kegiatan budidaya payau dan laut di wilayah pesisir Kabupaten Padang Pariaman. Disisi lain menurut Bappeda Padang Pariaman (2001c), minat masyarakat cukup besar terhadap kegiatan budidaya ini, hal ini terlihat dari respon positif masyarakat terhadap percontohan budidaya kepiting bakau di Naras

Untuk dapat mengembangkan kegiatan perikanan di wilayah pesisir Kabupaten Padang Pariaman, diperlukan strategi dan arahan yang representatif agar dapat mewujudkan pengembangan perikanan yang memberikan dampak positif secara merata kepada seluruh masyarakat. Strategi dan arahan yang representatif dapat dihasilkan dari analisis yang komprehensif tentang seluruh faktor internal dan eksternal yang terkait dengan pengembangan perikanan wilayah pesisir Kabupaten Padang Pariaman baik potensi sumberdaya, tingkat pemanfaatan, dan permasalahannya.

Penelitian ini bertujuan untuk: menganalisis faktor internal dan eksternal yang mempengaruhi pengembangan perikanan wilayah pesisir Kabupaten Padang Pariaman, serta menyusun strategi dan arahan pengembangannya yang berkelanjutan dan berwawasan lingkungan.

\section{METODE}

\section{Lokasi dan Waktu Penelitian}

Lokasi penelitian ini meliputi seluruh pusat-pusat kegiatan dan daerah potensial untuk kegiatan perikanan (tangkap dan budidaya) disepanjang wilayah pesisir Kabupaten Padang Pariaman. Penelitian ini telah dilaksanakan dalam dua tahap kegiatan, yaitu tahapan penelitian pendahuluan dan pengumpulan data sekunder yang dilaksanakan dari bulan Juli sampai dengan Agustus 2000. Sedangkan survai lapang dan pengambilan data primer dilaksanakan dari bulan Agustus sampai dengan September 2001 dan Januari 2002

\section{Metode Penelitian}

Penelitian ini berupa studi kasus yang bersifat deskriptif, yaitu menggambarkan atau menguraikan sifat dari suatu keadaan atau kondisi yang ada pada lokasi penelitian, yang dilanjutkan dengan menganalisis permasalahan yang ditemui. Survai dilakukan untuk megumpulkan data yang terbatas dari sejumlah kasus yang besar. Selanjutnya data yang diperoleh digunakan untuk memecahkan masalah tanpa harus melakukan pengujian hipotesis (Bengen, 1998).

\section{Pengumpulan Data}

Data dan informasi yang dikumpulkan terdiri atas data primer dan data sekunder. Data primer diperoleh dengan melakukan wawancara langsung dengan stakeholders yang terdiri atas masyarakat (10 orang per jenis alat tangkap per desa pesisir), tokoh masyarakat, dan pejabat pemda berdasarkan panduan daftar pertanyaan yang ditujukan untuk mengetahui tingkat pendidikan dan keterampilan, teknologi dan sarana penangkapan, kondisi sosial ekonomi, serta persepsi mereka terhadap pengelolaan sumberdaya pesisir. Pemilihan sampel untuk wawancara dilakukan secara purposive random sample.

Sedangkan data sekunder diperoleh dari dokumendokumen atau monografi instansi-instansi berwenang seperti: Bappeda, Dinas yang membidangi Kelautan dan Perikanan, Bapedalda, serta dinas dan instansi terkait lainnya baik ditingkat kabupaten maupun propinsi. Laporan hasil studi dari berbagai lembagal instansi yang relevan dan berbagai sumber lainnya.

\section{Analisis Data}

\section{Analisis potensi sumberdaya perikanan tangkap Kabupaten Padang Pariaman}

Potensi sumberdaya perikanan tangkap Kabupaten Padang Pariaman pada areal penangkapan yang 
sudah dimanfaatkan sampai saat ini dihitung dengan analisis Maximum Sustainable Yield (MSY). Analisis MSY yang digunakan adalah dengan metode Surplus Produksi (Spare and Venema, 1999). Untuk mengamankan daya pulih sumberdaya maka ditentukan jumlah tangkapan yang diperbolehkan (allowable cacth) sebesar $80 \%$ dari MSY (Anderson, L. G. 1974; Aziz, K. A., 1998).

\section{Analisis pemusatan produksi perikanan tangkap (comparative advantage)}

Location Quotient (LQ) merupakan suatu indeks untuk membandingkan pangsa sub wilayah dalam aktivitas perikanan tangkap dengan pangsa total aktivitas tersebut dalam total aktivitas wilayah. Secara lebih operasional, LQ didefinisikan sebagai rasio persentase dari total aktivitas perikanan tangkap pada sub wilayah ke-i terhadap persentase aktivitas total terhadap wilayah yang diamati.

Persamaan dari LQ adalah (Hermawan, 2001):
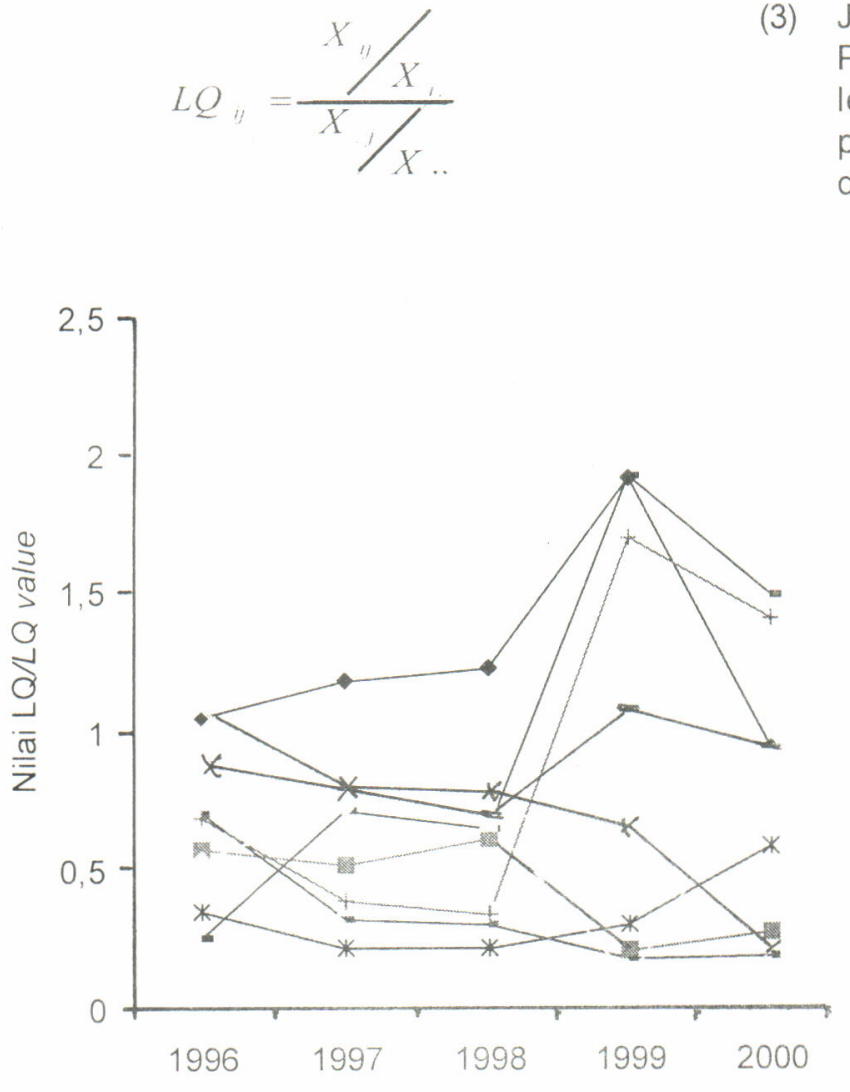

Tahun/Years
Keterangan:

Xij = produksi ikan jenis ke-j pada kabupaten ke-i (Padang Pariaman)

$\mathrm{Xi}$. = produksi total perikanan tangkap kabupaten kei (Padang Pariaman)

X.j $=$ produksi total jenis ikan ke-j di Sumatera Barat

$X$. . = produksi total perikanan tangkap Sumatera Barat

Untuk dapat menginterpretasikan hasil analisis LQ, terdapat suatu kesepakatan sebagai berikut:

(1) Jika nilai $L Q>1$, maka hal ini menunjukkan terjadinya konsentrasi produksi perikanan di kabupaten ke-i (Padang Pariaman) secara relatif dibandingkan dengan total wilayah (Sumatera Barat) atau terjadi pemusatan aktivitas di kabupaten ke-i (Padang Pariaman). Atau dapat disebut juga dengan surplus produksi pada kabupaten ke-i (Padang Pariaman)

(2) Jika nilai $L Q=1$, maka kabupaten ke-i tersebut mempunyai pangsa aktivitas perikanan tangkap setara dengan pangsa total Sumatera Barat.

(3) Jika $L Q<1$, maka kabupaten ke-i (Padang Pariaman) tersebut mempunyai pangsa relatif lebih kecil dibandingkan dengan aktivitas perikanan tangkap yang secara umum ditemukan di Sumatera Barat. Atau dapat juga

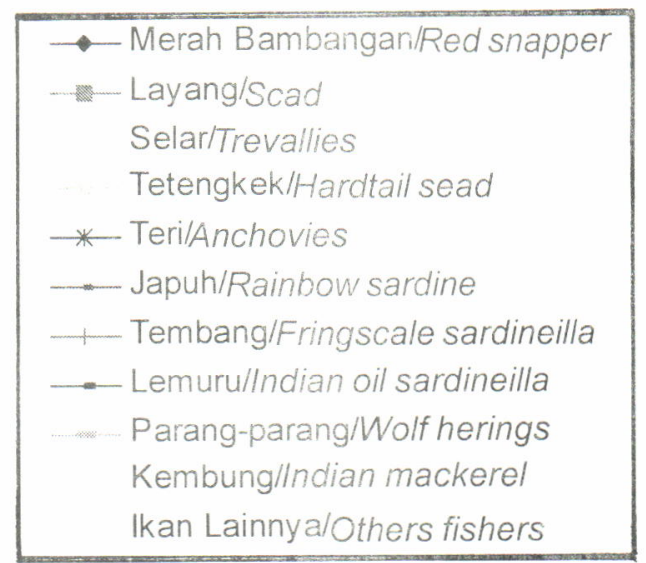

Gambar 1. Nilai LQ ikan-ikan pelagis kecil di Kabupaten Padang Pariaman, 1996-2000

Figure 1. LQ Value of small pelagic fish in Padang Pariaman, 1996-2000 
disebut defisit produksi di kabupaten ke-i (Padang Pariaman)

\section{Analisis Spesialisasi (SI)}

Analisis spesialisasi digunakan untuk melihat spesialisasi kabupaten terhadap jenis ikan tertentu. Penghitungan SI dapat dilakukan dengan persamaan berikut (Hermawan, 2001):

$$
S I=X_{11} / X_{1}-X_{1} / X
$$

Keterangan:

$X_{i j}=$ produksi ikan jenis ke-j pada kabupaten ke-i (Padang Pariaman)

Xi. = produksi total perikanan tangkap kabupaten kei (Padang Pariaman)

$X_{\text {.j }}=$ produksi total jenis ikan ke-j di Sumatera Barat spesialisasi aktivitas perikanan tangkap dibandingkan daerah lain di Sumatera Barat.

\section{Analisis kecenderungan kegiatan perikanan wilayah (comparative advantage)}

Pemahaman struktur aktivitas dari hasil analisis shift-share juga menjelaskan kemampuan berkompetisi (competitiveness) aktivitas tertentu di suatu wilayah secara dinamis atau perubahan aktivitas dalam cakupan wilayah lebih luas.

Persamaan analisis shift-share ini adalah sebagai berikut (Hermawan, 2001):

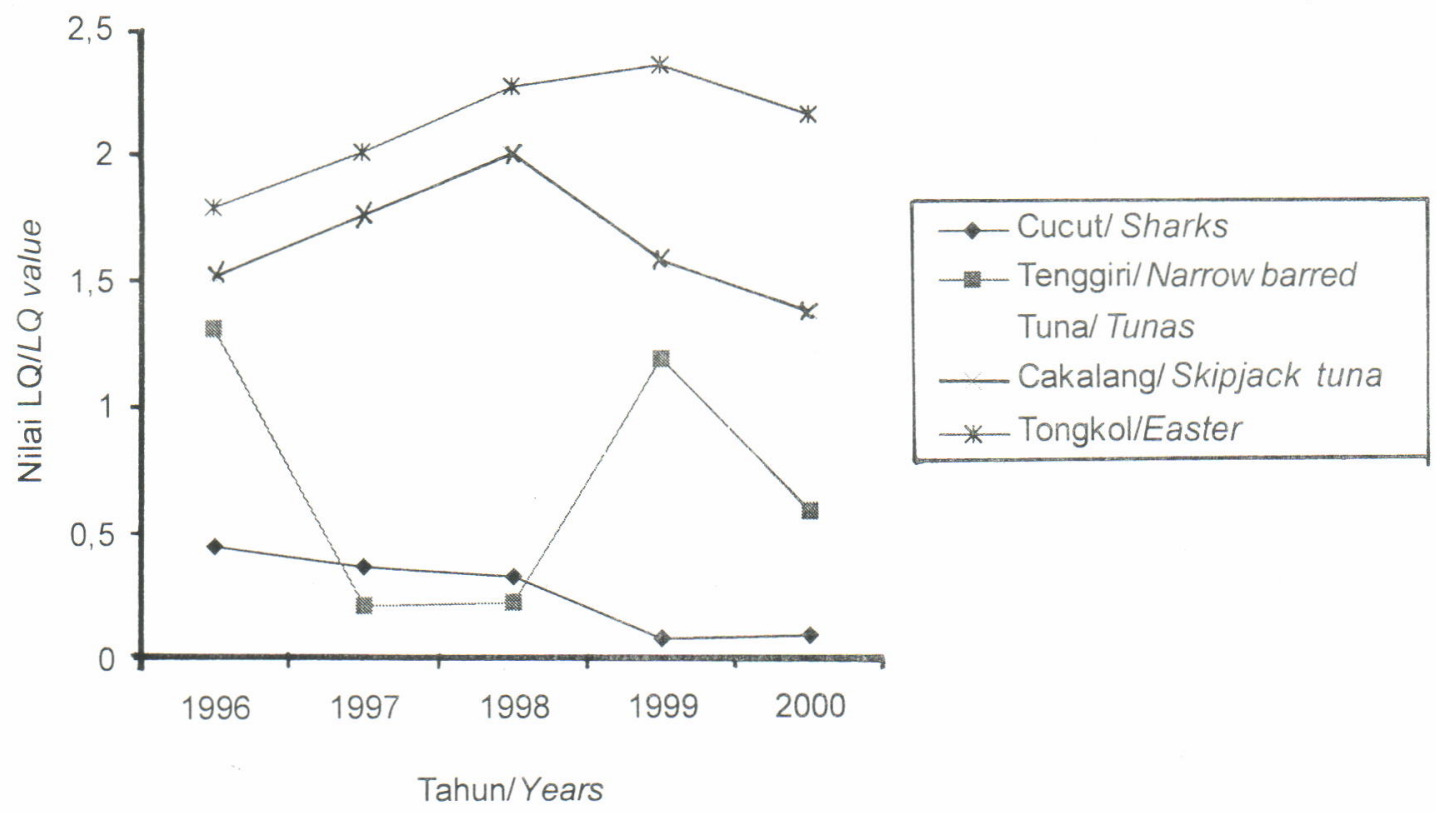

Gambar 2. Nilai LQ Ikan-ikan Pelagis Besar di Kabupaten Padang Pariaman 1996 - 2000

Figure 2. LQ Value of Big Pelagic Fish in Padang Pariaman, 1996-2000

X. = produksi total perikanan tangkap Sumatera Barat

(1) Jika nilai $\mathrm{SI}>1$, maka hal ini menunjukkan terjadinya spesialisasi produksi perikanan di kabupaten ke-i (Padang Pariaman) secara relatif dibandingkan daerah lain di wilayah yang lebih luas (Sumatera Barat).

(2) Jika SI < 1, maka kabupaten ke-i (Padang Pariaman) tersebut tidak mempunyai
Keterangan:

$\mathrm{a}=$ komponen share

b = komponen proportional shift

c = komponen differential shift, dan

$X_{i j}=$ produksi ikan jenis ke-j pada kabupaten ke-i (Padang Pariaman)

$\mathrm{Xi}$. = produksi total perikanan tangkap kabupaten kei (Padang Pariaman) 


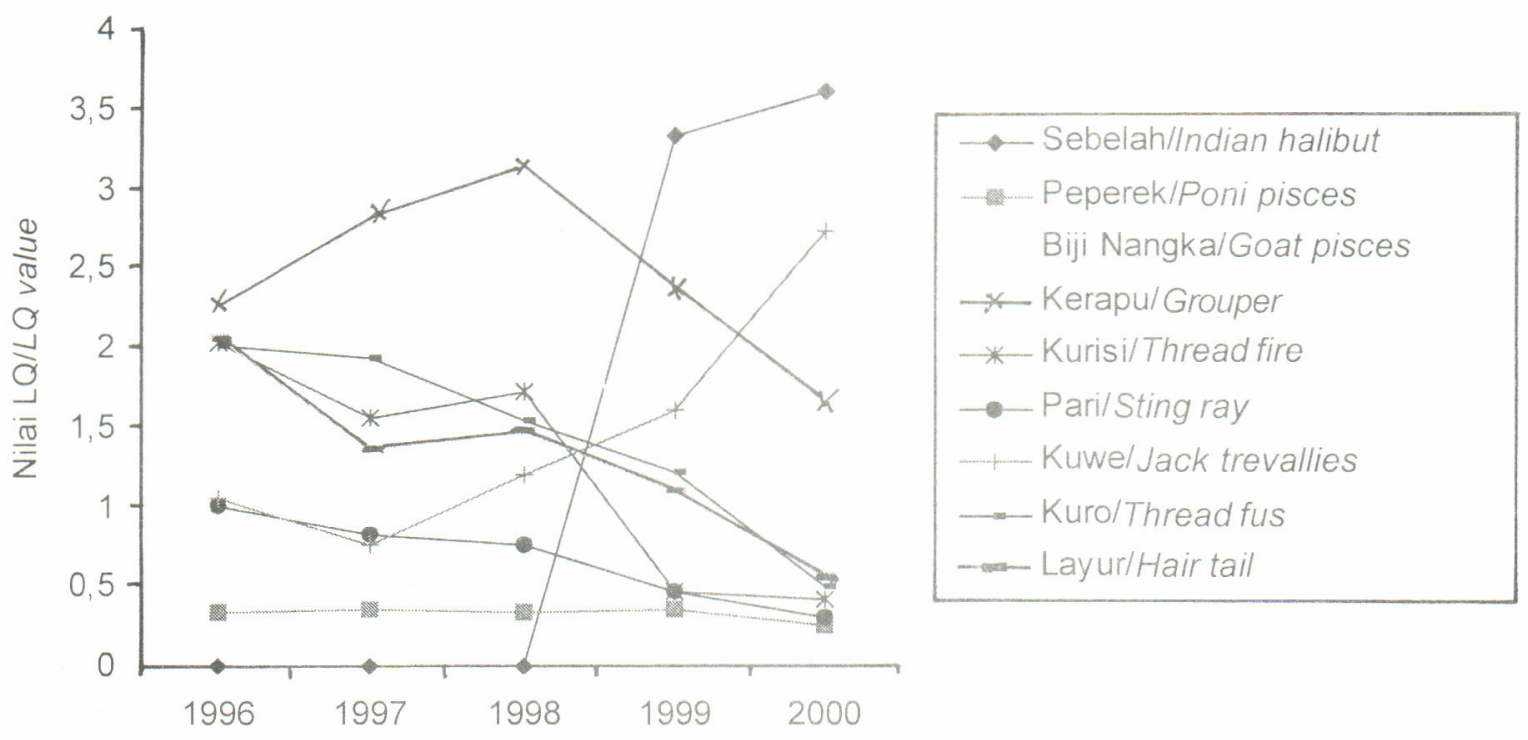

Tahun/Years

Gambar 3. Nilai LQ ikan-ikan demersal di Kabupaten Padang Pariaman 1996 - 2000

Figure 3. LQ value of demersal fish in Padang Pariaman, 1996-2000

$\mathrm{X} . \mathrm{j}=$ produksi total jenis ikan ke-j di Sumatera Barat

X.. = produksi total perikanan tangkap Sumatera Barat

$\mathrm{t} 1$ = titik tahun akhir

to = titik tahun awal

\section{Penentuan komoditas unggulan dan prioritas}

Untuk dapat menentukan jenis ikan unggulan yang dijadikan prioritas pengembangan perikanan tangkap di Kabupaten Padang Pariaman, dibuat matrik

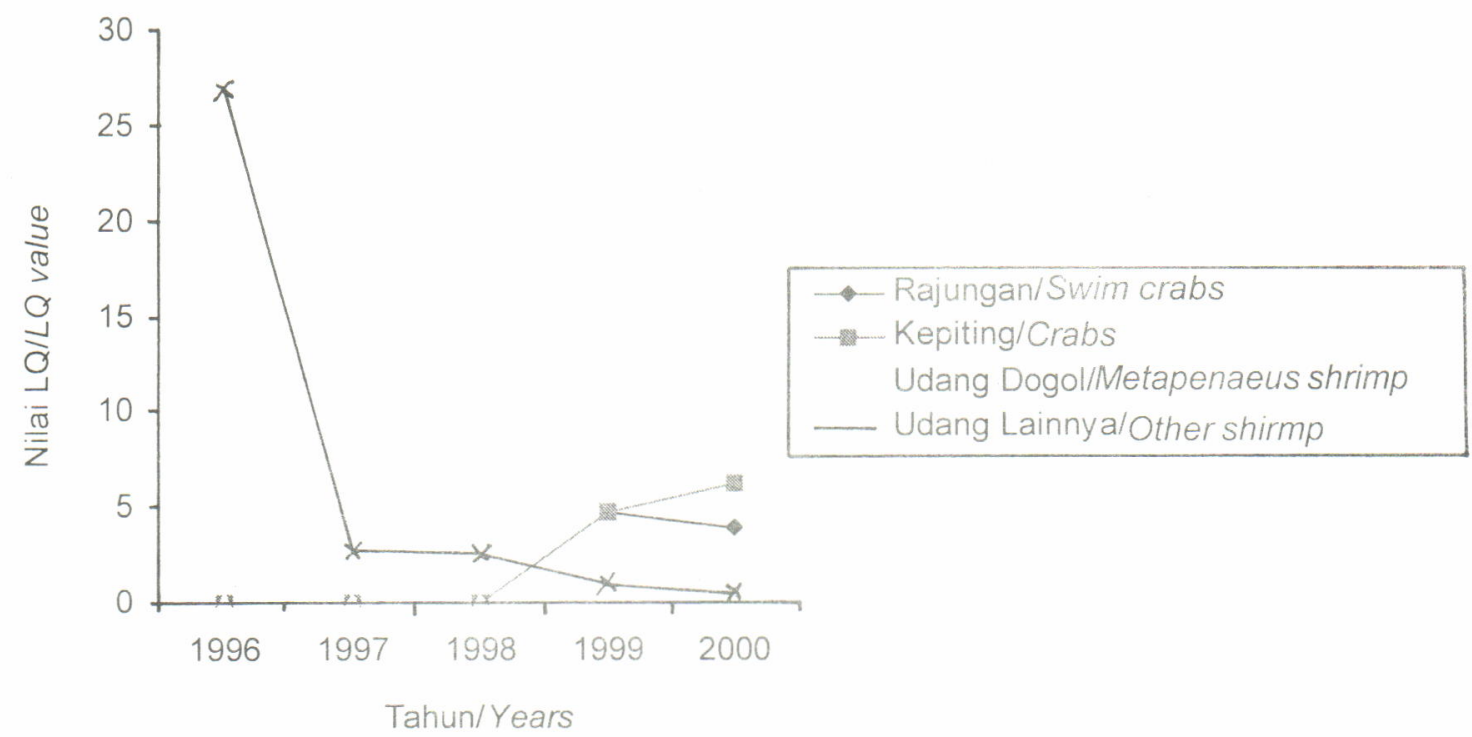

Gambar 4. Nilai LQ udang-udangan di kabupaten Padang Pariaman 1996 - 2000 Figure 4. LQ value of shrimp in Padang Pariaman, 1996-2000 
M. Rifqi, D. G. Bengen dan V. P. H. Nikijuluw

Tabel 1. Klasifikasi dan bobot nilai LQ, SI, dan SSA

Table 1. Classification and weight $L Q$, SI and SSA

\begin{tabular}{|c|c|c|c|}
\hline No. & Analisis/Analysis & Klasifikasi/lnterval & $\begin{array}{l}\text { Bobotl } \\
\text { weight }\end{array}$ \\
\hline \multirow[t]{4}{*}{1.} & Pertumbuhan/Growth & $>8,5 \%$ & 3 \\
\hline & & $7 \%-8,49 \%$ & 2 \\
\hline & & $0 \%-6,99 \%$ & 1 \\
\hline & & $<0 \%$ & 0 \\
\hline \multirow[t]{3}{*}{2.} & Nilai Location Quotient (LQ) & $>1$ & 2 \\
\hline & & $0,80-0,99$ & 1 \\
\hline & & $<0,79 \%$ & 0 \\
\hline \multirow[t]{3}{*}{3.} & Pertumbuhan LQ/Growth $L Q$ & Positif/Positive & 2 \\
\hline & & Tetap/Fixed & 1 \\
\hline & & Negatif/Negative & 0 \\
\hline \multirow[t]{3}{*}{4.} & Nilai & $>1$ & 2 \\
\hline & Spesialisasi/Specialization & $0,80-0,99$ & 1 \\
\hline & & $<0,79 \%$ & 0 \\
\hline \multirow[t]{3}{*}{5.} & Pertumbuhan/Growth (SI) & Positif/Positive & 2 \\
\hline & & Tetap/Fixed & 1 \\
\hline & & Negatif/Negative & 0 \\
\hline \multirow[t]{2}{*}{6.} & Shift Share Analysis (SSA) & Positif/Positive & 2 \\
\hline & & Negatif/Negative & 0 \\
\hline
\end{tabular}

Sumber: Modifikasi dari Azman, 2001

Sorce: Modified from Azman, 2001

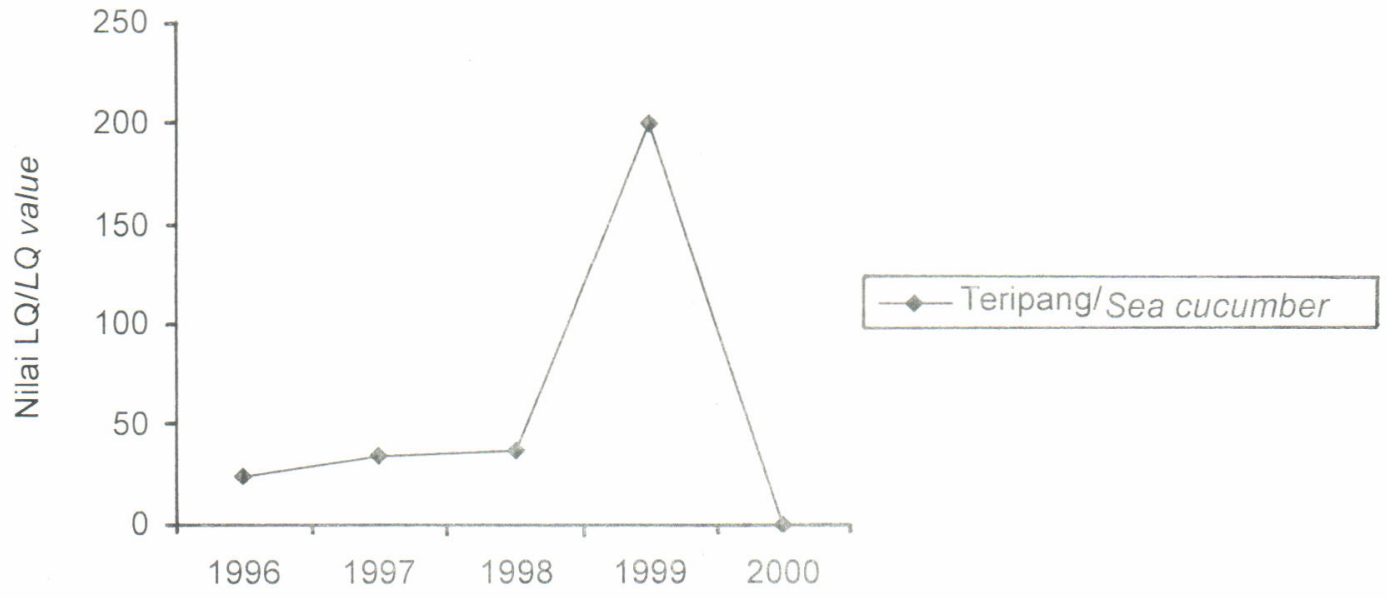

Tahun/Years

Gambar 5. Nilai LQ teripang di Kabupaten Padang Pariaman, 1996 - 2000

Figure 5. LQ value of sea cucumber in Padang Pariaman, 1996-2000

gabungan dari beberapa pendekatan yaitu: laju pertumbuhan produksi, Location Quotient (LQ), Spesialisasi (SI), dan Shift Share Analysis (SSA)

\section{Analisis faktor eksternal}

Faktor eksternal yang berpengaruh terhadap pengembangan perikanan wilayah pesisir Kabupaten Padang pariaman disampaikan secara deskriptif, diantaranya potensi sumberdaya ikan di perairan
Sumatera Barat dengan analisis MSY dan posisi/ kontribusi sektor perikanan terhadap PDRB Kabupaten Padang Pariaman dengan analisis LQ, SI, dan SSA

\section{Analisis SWOT}

Dengan memperhatikan keseluruhan faktor internal dan eksternal pengembangan perikanan pesisir Kabupaten Padang Pariaman, maka dengan 
Tabel 2. Produksi perikanan tangkap, pemanfaatan, dan kemungkinan dapat ditingkatkan di Kabupaten Padang Pariaman tahun 1996-2000

Table 2. Capture fisheries production, utilization and possibility of increase in Padang Pariaman, years 1996-2000

\begin{tabular}{cccccc}
\hline $\begin{array}{c}\text { Tahun/ } \\
\text { Years }\end{array}$ & $\begin{array}{c}\text { Upaya/trip } \\
\text { EffortTrip }\end{array}$ & $\begin{array}{c}\text { Produksi/ } \\
\text { Production } \\
\text { (ton) }\end{array}$ & $\begin{array}{c}\text { Peningkatan/ } \\
\text { Rate of } \\
\text { increase (\%) }\end{array}$ & $\begin{array}{c}\text { Tingkat } \\
\text { Pemanfaatan/ } \\
\text { Exploitation } \\
\text { rate }^{*} \text { (\%) }\end{array}$ & $\begin{array}{c}\text { Dapat } \\
\text { Ditingkatkan/ } \\
\text { Possib/e } \\
\text { increase }^{*} \text { (\%) }\end{array}$ \\
\hline 1996 & 75.645 & $25.650,30$ & - & 86,43865 & 13,56135 \\
1997 & 70.922 & $25.949,20$ & 1,16529 & 87,44591 & 12,55409 \\
1998 & 70.913 & $26.954,20$ & 3,87295 & 90,83265 & 9,167348 \\
1999 & 56.121 & $27.038,60$ & 0,31312 & 91,11707 & 8,882929 \\
2000 & 55.808 & $25.913,20$ & $-4,1622$ & 87,3246 & 12,6754 \\
\hline
\end{tabular}

Sumber: Hasil Analisis

) setara alat tangkap pancing lainnya/Equivalent to hook gear

pendekatan analisis SWOT (Strength, Weakness, Opportunity, and Threat) dapat disusun faktor-faktor strategis eksternal berupa peluang dan ancaman, serta faktor strategis internal berupa kekuatan dan kelemahan. Setelah melalui proses pembobotan dan rangking dapat diketahui urutan tingkat kepentingan faktor-faktor tersebut, baik strategis eksternal maupun strategis internal (Rangkuti, 2000).

\section{HASIL DAN BAHASAN}

\section{Potensi Sumberdaya Perikanan Tangkap}

Berdasarkan hasil perhitungan potensi sumberdaya ikan di perairan pantai Kabupaten Padang Pariaman dengan menggunakan model Surplus Production dengan metode Fox diketahui potensi
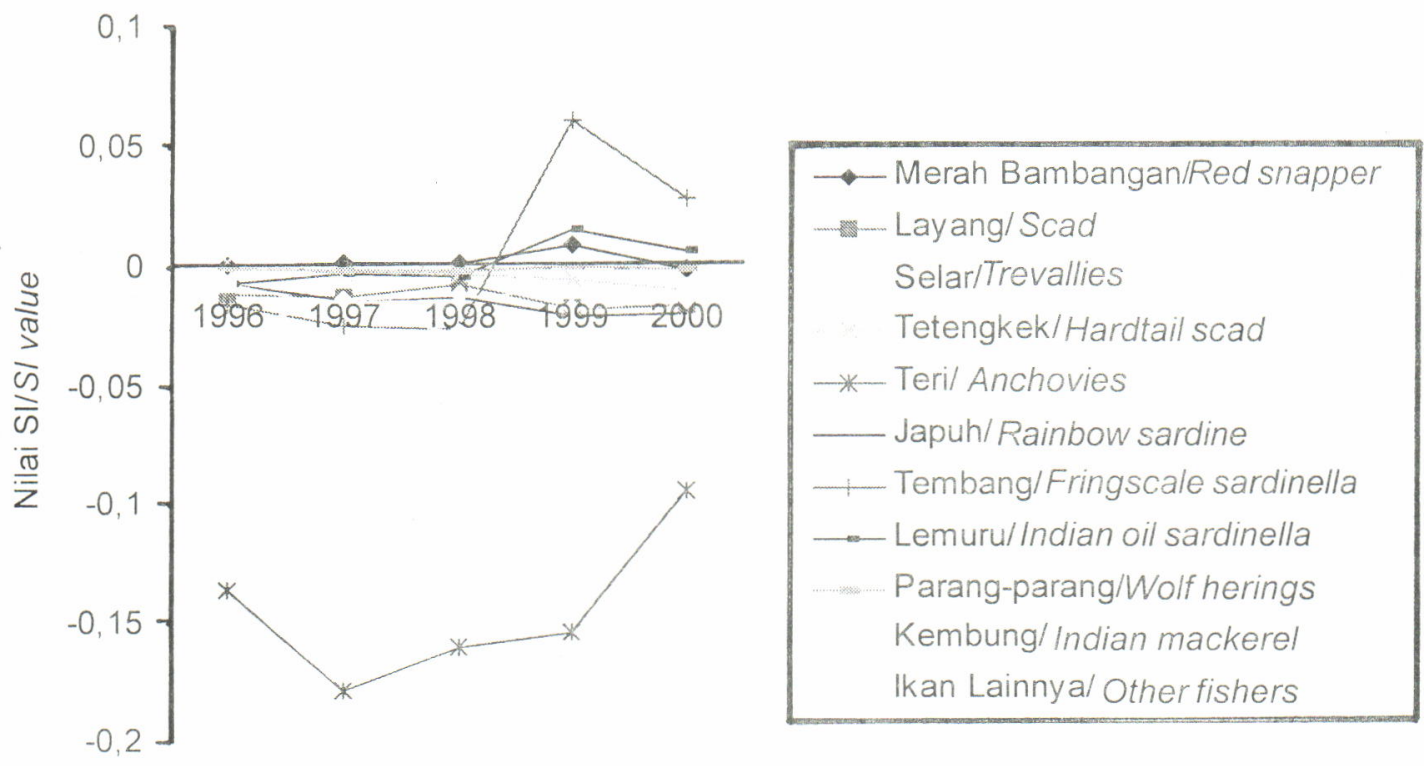

Tahun/Years

Gambar 6. Nilai SI ikan-ikan pelagis kecil di kabupaten Padang Pariaman, 1996 - 2000 Figure 6. SI value of small-pelagic fish in Padang Pariaman, 1996-2000 


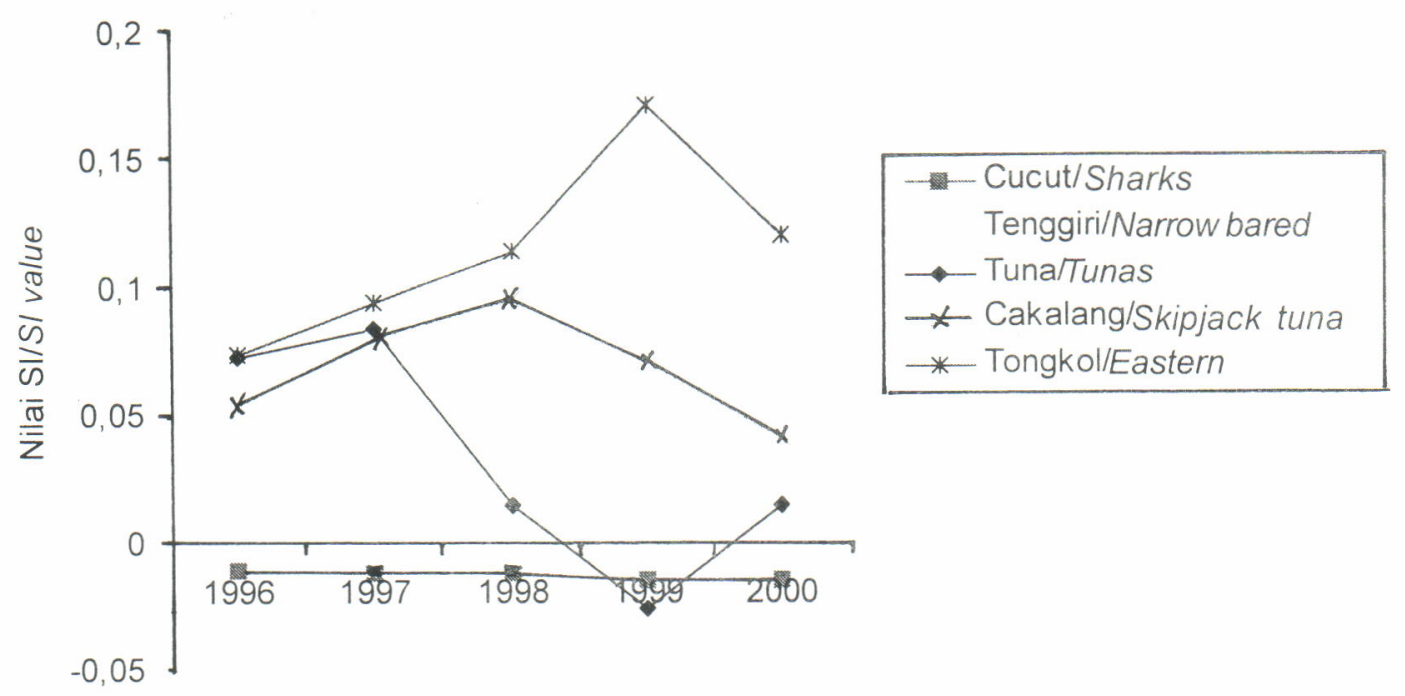

Tahun/Years

Gambar 7. Nilai SI Ikan-ikan Pelagis Besar di Kabupaten Padang Pariaman 1996 - 2000

Figure 7. SI Value of Small Pelagic Fish in Padang Pariaman, 1996-2000

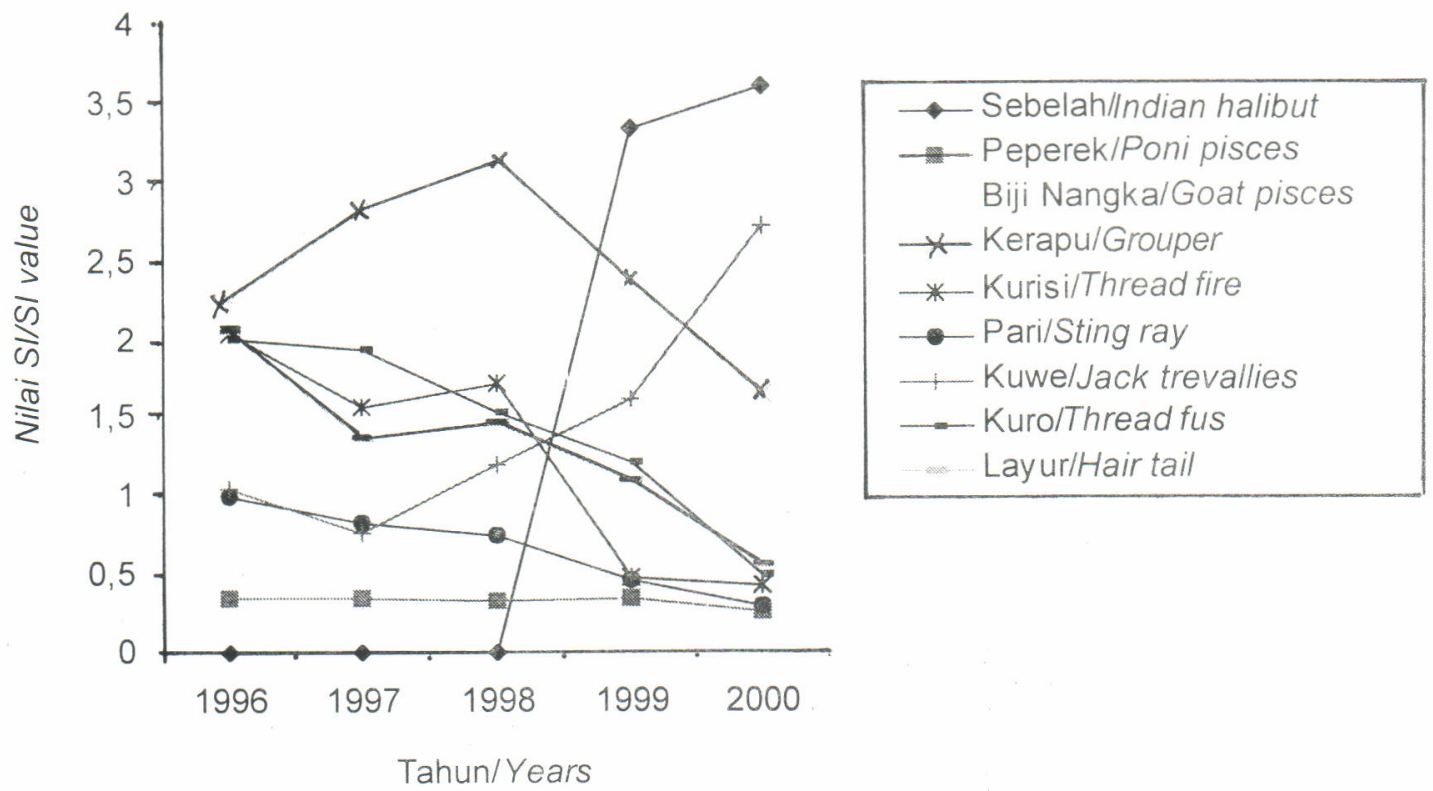

Gambar 8. Nilai SI Ikan-ikan Demersal di Kabupaten Padang Pariaman $1996-2000$

Figure 8. SI Value of Demersal in Padang Pariaman, 1996-2000

maksimum lestari (MSY) untuk semua jenis ikan adalah 29.675 ton per tahun dengan upaya optimum $58.074,62$ trip per tahun setara dengan alat tangkap pancing lainnya.

Dari Tabel 2 di atas terlihat bahwa produksi perikanan tangkap Kabupaten Padang Pariaman masih berada dibawah MSY atau potensinya. Namun jika mengacu pada jumlah tangkap yang diperbolehkan (allowable cacth) sebesar $80 \%$ dari MSY, maka pemanfaatan sumberdaya perikanan di perairan pantai Kabupaten Padang Pariaman dari tahun 1996 - 2000 telah melebihi JTB (jumlah tangkap diperbolehkan) tetapi masih di bawah MSY, artinya pemanfaatan sumberdaya perikanan tersebut sudah 


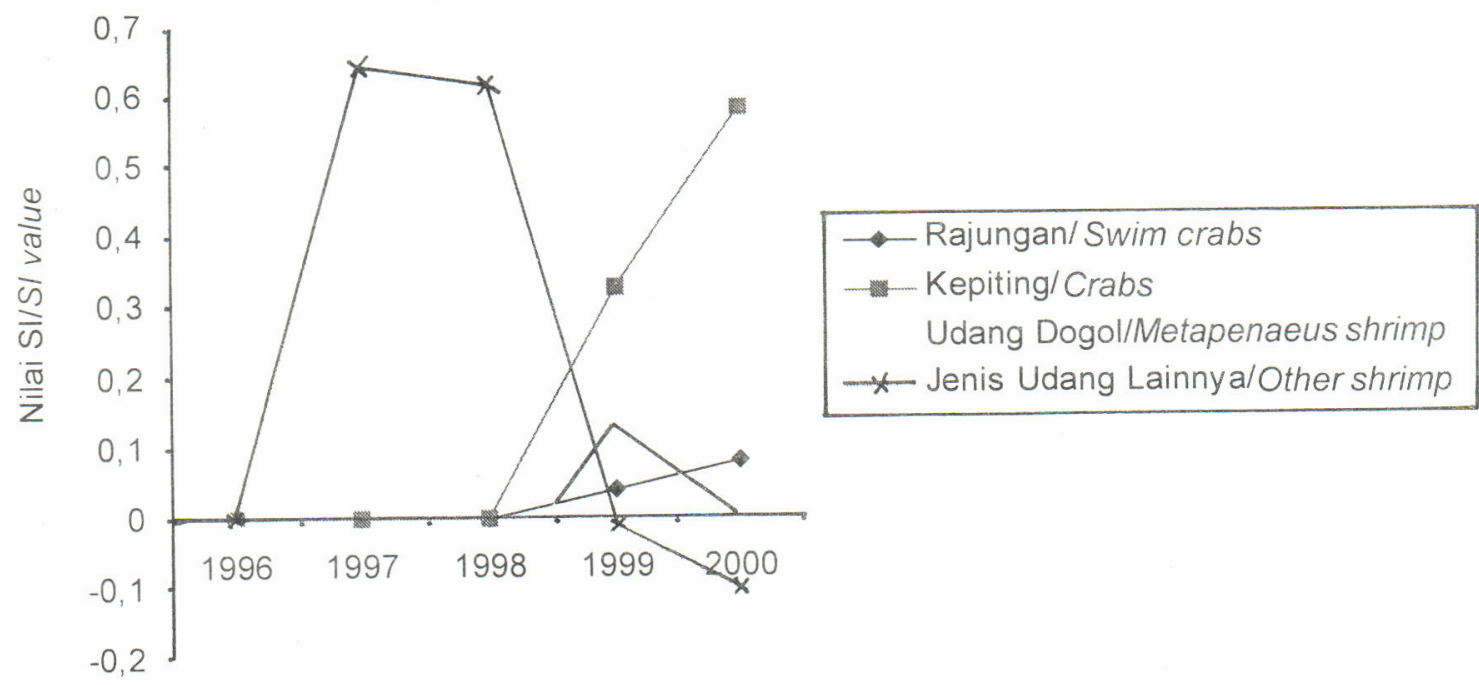

Tahun/Years

Gambar 9. Nilai SI udang-udangan di Kabupaten Padang Pariaman, 1996 - 2000

Figure 9. SI value of shrimp in Padang Pariaman, 1996-2000

melewati titik aman pemanfaatannya. Tingginya tingkat pemanfaatan ini dimungkinkan karena kecilnya kemampuan jelajah armada perikanan tangkap di Kabupaten Padang Pariaman (sebagian besar < 5 GT) sehingga daerah cakupan penangkapan relatif kecil.

Pemanfaatan yang melebihi JTB dikuatirkan akan mengancam kelestarian sumberdaya perikanan, apalagi jika kondisi tersebut secara simultan dengan terjadinya penurunan kualitas lingkungan dan degradasi habitat. Sehingga pengembangan perikanan tangkap di wilayah pesisir pantai Kabupaten Padang Pariaman lebih diarahkan pada pengembangan armada penangkapan untuk mendapatkan daya jelajah yang lebih jauh.

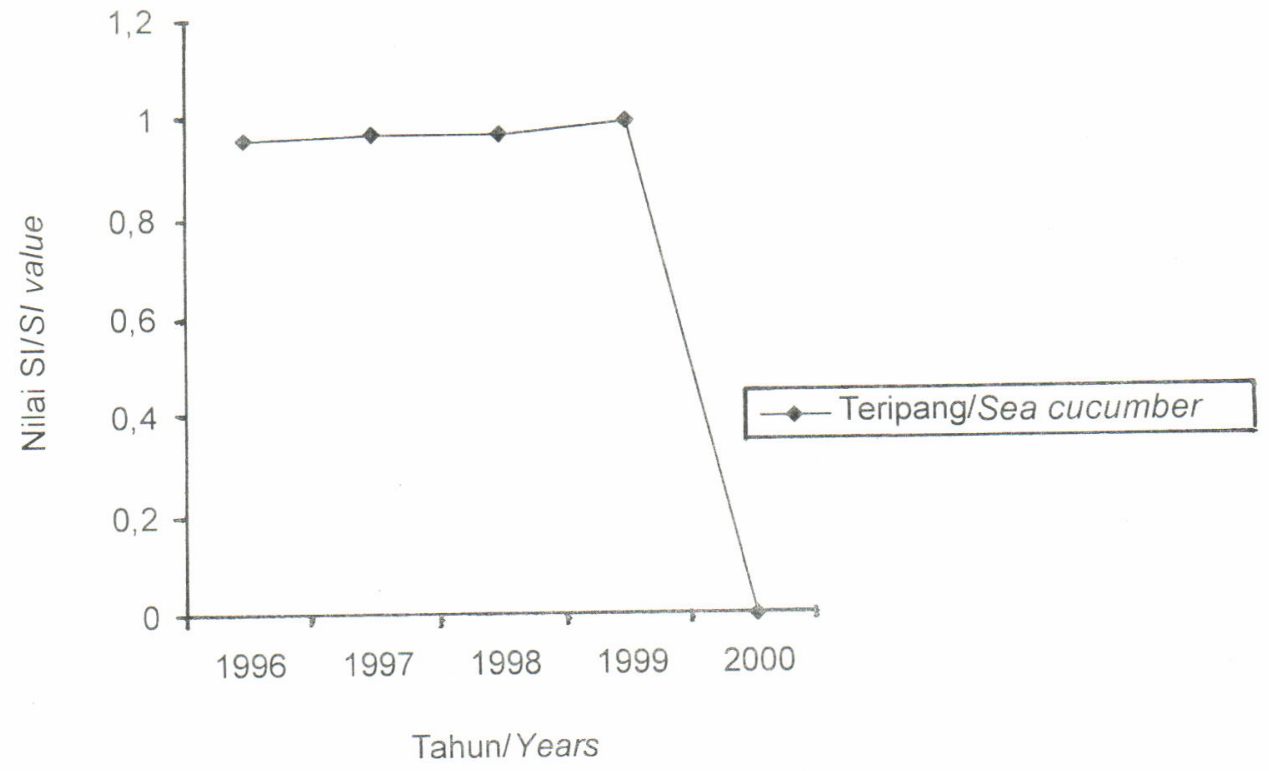

Gambar 10. Nilai SI teripang di Kabupaten Padang Pariaman, 1996 - 2000

Figure 10. SI value of sea cucumber in Padang Pariaman, 1996-2000 


\section{Pemusatan Produksi Perikanan Tangkap}

Nilai LQ jenis-jenis ikan yang didaratkan di Kabupaten Padang Pariaman selama 5 tahun (1996 - 2000) terjadi fluktuasi dari tahun ke tahun seperti ditampilkan pada Gambar 1, Gambar, 2, Gambar 3, Gambar 4, dan Gambar 5. Fluktuasi yang terjadi juga beragam menurut jenis ikannya, ada fluktuasi naik turun yang cenderung naik, dan ada juga fluktuasi naik turun yang cenderung menurun. Sedangkan adanya perubahan-perubahan ekstrim terutama setelah tahun 1999, dimungkinkan karena sistem pendataan yang berubah dengan adanya pemekaran Kabupaten Kepulauan Mentawai.

Dari kelima gambar tersebut dapat disampaikan bahwa jenis ikan pelagis kecil yang mengalami surplus produksi atau terpusat di Kabupaten Padang Pariaman adalah ikan merah bambangan dari tahun 1996 sampai tahun 1999. Ikan tetengkek pada tahun 1996, ikan lemuru dan tembang pada tahun 1999 sampai tahun 2000, sedangkan ikan golok-golok/ parang-parang hanya pada tahun 1999. Tiga dari lima jenis ikan pelagis besar menunjukkan surplus produksi sepanjang tahun, kecuali tuna yang sempat defisit pada tahun 1999

Tahun 1996-1999 hampir semua jenis ikan demersal berada posisi surplus produksi, kecuali ikan peperek. Tetapi tahun 2000 beberapa jenis seperti kurisi, pari, kuro/senangin dan layur mengalami defisit produksi. Sedangkan nilai LQ kelompok udangudangan menampilkan fluktuasi yang ekstrim kecuali jenis udang lainnya yang memperlihatkan fluktuasi yang cenderung menurun. Semua jenis udangudangan pernah mengalami surplus produksi atau terpusat di Kabupaten Padang Pariaman. Dan jenis binatang laut lainnya, dimana teripang sebagai produk Kabupaten Padang Pariaman satu-satunya pada kelompok ini tahun 1999

\section{Spesialisasi Produksi Perikanan Tangkap}

Melihat nilai SI semua kelompok jenis ikan seperti ditampilkan pada: Gambar 6, Gambar 7, Gambar 8, Gambar 9, dan Gambar 10, dapat dinyatakan bahwa produksi perikanan tangkap Kabupaten Padang Pariaman tidak memiliki kekhasan selama tahun 1996 sampai dengan tahun 2000

\section{Kecenderungan Kegiatan Perikanan Wilayah}

Hasil penghitungan komponen "share", komponen pergeseran proporsional, dan komponen pergeseran differensial, produksi perikanan tangkap Kabupaten Padang Pariaman tahun 1996 sampai dengan tahun 2000 ditampilkan pada Lampiran 1. Komponen "share" sebesar 0,193 yang berarti terjadi pertumbuhan sebesar 0,193. Komponen "share" ini dibedakan atas komponen "share" kelompok ikan-ikan yakni 0,188, udang-udangan sebesar 0,391, dan kelompok binatang laut lainnya sebesar $-0,1$ yang berarti mengalami pertumbuhan sebesar angka-angka tersebut.

\section{Komoditas Unggulan dan Prioritasnya}

Komoditas unggulan untuk kegiatan penangkapan berdasarkan hasil penghitungan matriks gabungan dapat dijadikan prioritas sepuluh tertinggi di Kabupaten Padang Pariaman yang secara berurutan adalah: ikan tongkol dengan bobot 20; kuwe dengan bobot 19; lemuru dan tembang dengan bobot 15; parang-parang dan ikan lainnya dengan bobot 13; cakalang dengan bobot 12; selar dengan bobot 11; kerapu, kuro, kepiting, dan jenis udang lainnya dengan bobot 9; layur, tuna, udang dogol, dan teripang dengan bobot 8; serta ikan kembung dengan bobot 7 .

\section{Potensi Perikanan Budidaya Payau dan Laut}

Kecamatan dan desa wilayah pesisir di Kabupaten Padang Pariaman yang memenuhi persyaratan umum untuk lokasi budidaya pantai dapat dilihat pada Tabel 3 .

Komoditas yang mempunyai nilai ekonomis penting yang dapat dibudidayakan berbadasarkan analisis potensi kawasan adalah udang windu (Penaeus monodon), kepiting bakau (Scylla serrata) ikan bandeng (Chanos chanos), dan kerang (lokan) (Bappeda Padang Pariaman, 2001c).

\section{Teknologi Perikanan}

Teknologi bidang perikanan yang sudah berkembang di pesisir Kabupaten Padang Pariaman adalah teknologi pada kegiatan perikanan tangkap Sedangkan teknologi untuk kegiatan budidaya lau maupun payau hampir belum ada sama sekali. $\mathrm{Ha}$ ini dimungkinkan oleh kondisi fisik wilayah yang sangat dinamis.

Berbagai jenis sumberdaya laut telah dimanfaatkan oleh masyarakat di Kabupaten Padang Pariaman. Dari data dan informasi didapatkan gambaran bahwa ikan tongkol (Euthynus sp), ikan cakalang (Katsuwonus $s p$ ), dan ikan kembung (Restrellinger $s p$ ) yang paling banyak ditangkap. Kegiatan penangkapan tersebut dilakukan dengan beberapa jenis alat tangkap (seperti ditampilkan pada Tabel 4) dan ukuran (tonase) armada penangkap yang sebagian besar < 5 GT .

Berdasarkan Tabel 4 terlihat bahwa alat tangkap yang paling banyak di Kabupaten Padang Pariaman adalah gillnet dan payang. Kondisi memungkinkan 
Tabel 3. Kecamatan dan desa di wilayah pesisir Kabupaten Padang Pariaman yang memenuhi persyaratan umum lokasi untuk budidaya pantai

Table 3. Distric and village an the coastal area of Padang Pariaman which meet general criteria for brackish water culture

\begin{tabular}{|c|c|c|c|}
\hline No. & $\begin{array}{l}\text { Kecamatan/ } \\
\text { Sub-District }\end{array}$ & Desa/village & $\begin{array}{c}\text { Kriteria Umum Lokasi Budidaya/ General criteria for } \\
\text { aquaculture location }\end{array}$ \\
\hline 1. & Sungai Limau & a. Tanjung & - Terdapat areal pasang surut/Existance of tidal area \\
\hline & & b. Malai Bawah & - Bebas banjir dan bencana alam/Free of flood \\
\hline 2. & Pariaman & Naras & - Tidak tercemar/No pollution \\
\hline 3. & Nan Sabaris & Sunur & $\begin{array}{l}\text { - Dapat mencapai sumber benur/benih/Can reached the } \\
\text { source of seed }\end{array}$ \\
\hline 4. & Ulakan & Batang Tiram & - Memiliki daerah pemasaran/Marketing place \\
\hline 5. & Batang Anai & Ketaping Selatan & $\begin{array}{l}\text { - Memiliki infrastruktur yang kuat/Powerfull infrastructure } \\
\text { - Dapat menjangkau sumber saprokan/Can reaced the source } \\
\text { of production factor }\end{array}$ \\
\hline
\end{tabular}

Sumber: Bappeda Padang Pariaman (2001c)

Source: Bappeda of Padang Pariaman (2001c)

Tabel 4. Jumlah per jenis alat tangkap ikan di Kabupaten Pariaman

Table 4. Number of fishing gear by sub district in Padang Pariaman

\begin{tabular}{|c|c|c|c|c|c|c|c|c|c|c|c|c|}
\hline \multirow[t]{2}{*}{ No. } & \multirow{2}{*}{$\begin{array}{c}\text { Nama Kecamatan/ } \\
\text { District }\end{array}$} & \multicolumn{3}{|c|}{ Pukat/seine } & \multicolumn{2}{|c|}{ Jaring/Net } & \multicolumn{2}{|c|}{$\begin{array}{l}\text { Bagan/ } \\
\text { Lifnet }\end{array}$} & \multicolumn{3}{|c|}{$\begin{array}{c}\text { Pancing/Pole and } \\
\text { line }\end{array}$} & \multirow[t]{2}{*}{$\begin{array}{l}\text { Jumlah } \\
\text { Total }\end{array}$} \\
\hline & & 1 & 2 & 3 & 4 & 5 & 6 & 7 & 8 & 9 & 10 & \\
\hline 1 & Sungai Limau & 36 & 21 & 13 & 133 & 9 & 1 & 15 & 35 & 42 & - & 305 \\
\hline 2 & Kampung Dalam & - & 29 & - & - & - & - & - & - & - & - & 29 \\
\hline 3 & Pariaman Utara & 10 & 22 & - & 16 & - & 24 & - & - & - & - & 72 \\
\hline 4 & Pariaman Tengah & 3 & - & - & 1 & - & 18 & 4 & - & - & 8 & 34 \\
\hline 5 & Pariaman Selatan & 9 & - & - & - & - & - & 5 & - & - & & 14 \\
\hline 6 & Ulakan Tapakis & 23 & 11 & - & 99 & - & - & - & - & - & 81 & 214 \\
\hline 7 & Nan Sabaris & - & - & - & 15 & - & - & - & - & - & - & 15 \\
\hline 8 & Batang Anai & 18 & - & 8 & 33 & - & - & - & - & - & - & 95 \\
\hline
\end{tabular}

Sumber/Source: Bappeda Padang Pariaman, 2001b

Keterangan/Note:

$\begin{array}{lll}1=\text { Payang/seine } & 4=\text { Gillnet } & 7=\text { Colok/liftnet } \quad 10=\text { Pancing Lainnya/ other pole and line } \\ 2=\text { Lorilseine } & 5=\text { Trammel net } & 8=\text { Tonda/pole and line } \\ 3=\text { Osoh/seine } & 6 \text { = Bagan/liftnet } & 9=\text { Rawai/hook and line }\end{array}$

kenyataan bahwa ikan yang paling banyak didaratkan di Kabupaten Padang Pariaman adalah tongkol, cakalang, dan kembung.

\section{Sosial, Ekonomi, dan Budaya Masyarakat Pesisir}

Penduduk asli Padang Pariaman terdiri atas 95\% suku Minang. Berdasarkan data sensus tahun 2000 jumlah penduduk Kabupaten Padang Pariaman yang berada di kecamatan pesisir adalah sebanyak 50.680 jiwa atau 10,6\% dari penduduk keseluruhan.
Sistem pemasaran produk perikanan hasil studi Bappeda Padang Pariaman (2001b) menyimpulkan terdapat dua jalur pemasaran. Jalur tersebut adalah Pertama pemasaran ikan-ikan segar dari tangkapan bagan, payang, pancing, dan jaring. Pada jalur pemasaran ini nelayan menyerahkan hasil tangkapan kepada agen yang telah ditunjuk. Pemiliki juga dapat bertindak sebagai agen. Agen ini akan menjual ikan tersebut kepada pedagang pengumpul atau di sendiri yang bertindak sebagai pengumpul. Pedagang atau agen selanjutnya melakukan penanganan pada ikan dengan cara pemberian es. Daerah pemasaran adalah 
daerah Sumatera Barat dan ke luar daerah seperti: Pekanbaru, Bangko, dan Jambi. Kedua, adalah jalur pemasaran/distribusi ikan teri olahan. Nelayan mendaratkan hasil tangkapan di pantai, dan langsung dibawa ke lokasi pengolahan (pondok teri) dari masingmasing pemiliki, untuk dilakukan pengolahan. Ikan teri olahan ini dibawa langsung ke gudang teri pedagang pengumpul di Padang.

\section{Persepsi Masyarakat Terhadap Sumberdaya Pesisir}

Hasil studi yang dilakukan Bappeda Padang Pariaman (2001b) menyimpulkan bahwa kesadaran masyarakat daerah pesisir Kabupaten Padang Pariaman terhadap sumberdaya alam dan lingkungan dapat dikatakan rendah. Penduduk belum menyadari hubungan yang saling terkait antar ekosistem wilayah pesisir, hubungan timbal balik, dan sebab akibat dari suatu aktivitas di wilayah pesisir terhadap lingkungannya

\section{Posisi Sub Sektor Perikanan dalam \\ Perekonomian Kabupaten Padang Pariaman}

Kegiatan perikanan di dalam struktur perekonomian Kabupaten Padang Pariaman merupakan salah satu sub sektor dari sektor pertanian. Analisis LQ sektorsektor PDRB oleh Azman (2001) menyatakan bahwa sektor pertanian merupakan salah satu sektor basis dalam perekonomian Kabupaten Padang Pariaman yang menempati prioritas pertama dalam penekanan perekonomian secara sektoral. Dimana pada penekanan pengembangan perekonomian pada sub sektor lapangan usaha maka sub sektor perikanan menempati prioritas utama

Struktur perekonomian Kabupaten Padang Pariaman selama periode tahun 1995 sampai 1999 masih didominasi oleh sektor pertanian yang terlihat dari besarnya kontribusi dari sektor tersebut terhadap pembentukan PRDB dan penyediaan lapangan pekerjaan. Tetapi besarnya kontribusi sektor pertanian ini terhadap PDRB setiap tahunnya sudah mulai menunjukkan adanya penurunan

\section{Ketersediaan Sarana dan Prasarana Perikanan Tangkap}

Secara umum sarana dan prasarana perikanan tangkap di Kabupaten Padang Pariaman sudah tersedia, walaupun kondisinya dan kapasitas yang ada saat ini belum memadai, serta pemanfaatannya belum optimal seperti cold storage di TPI Pasir Baru. Sarana untuk kegiatan perikanan tangkap berupa dermaga, pelabuhan, pendaratan ikan, serta tempat pelelangan ikan yang ada belum mampu mendukung kegiatan perikanan dengan armada penangkap (kapal) yang lebih besar

Sedangkan ketersediaan prasarana pendukung kegiatan perikanan tangkap seperti: jalan, sarana transportasi, listrik, dan sarana telokomunikasi telah tersedia hampir diseluruh wilayah pesisir Kabupaten Padang Pariaman. Dukungan prasarana ini akan semakin besar dengan adanya pembangunan Bandara Internasional Ketaping di salah satu kecamatan Kabupaten Padang Pariaman.

\section{Strategi dan Arahan Pengembangan Perikanan Wilayah Pesisir Kabupaten Padang Pariaman}

Arahan dan prioritas alternatif strategi pengembangan perikanan wilayah pesisir Kabupaten Padang Pariaman hasil analisis SWOT adalah sebagai berikut;

(1) Optimalisasi pemanfaatan sumberdaya perikanan, yang terdiri atas: peningkatan teknologi penangkapan, kapasitas armada penangkap ikan, serta sarana pelabuhan dermaga, dan tempat pendaratan ikan; dan upaya pengembangan kegiatan budidaya sesuai daya dukung lingkungan.

(2) Kebijakan yang kondusif (mendukung) perkembangan usaha perikanan, yang terdiri atas: penetapan tata ruang wilayah pesisir, investasi pemerintah dalam penyediaan sarana dan prasarana usaha perikanan (tangkap dan budidaya), dan upaya menciptakan peraturan tentang perijinan dan perpajakan/retribusi dengan prinsip win-win solution.

(3) Peningkatan produktifitas usaha perikanan melalui peningkatan teknologi usaha perikanan (penangkapan dan pengolahan) serta diversifikasi usaha masyarakat pesisir.

(4) Peningkatan kemampuan teknis, manajemen dan modal usaha nelayan, melalui pendidikan dan pelatihan pelaku usaha perikanan serta memfasilitasi aksesibilitas nelayan terhadap sumber modal (lembaga permodalan).

(5) Pengembangan perikanan terpadu, aspiratif dan aplikatif; yang keterpaduan meliputi backwardlinkage industries (seperti: perkapalan, peralatan tangkap, perbengkelan, perbekalan, pakan ikan, dil) maupun foreward-linkage industries (seperti: pabrik pengalengan ikan, tepung ikan, sosis, dll). Dan kegiatan perikanan yang dikembangkan harus dapat melibatkan masyarakat sebesarbesarnya

(6) Pengembangan teknologi perikanan ramah lingkungan; yang meliputi penerapan teknologi penangkapan dan budidaya yang berwawasan 
lingkungan, serta didukung upaya perbaikan dan perlindungan ekosistem.

(7) Investasi pemerintah terhadap sektor perikanan wilayah pesisir, terutama dalam penyediaan sarana dan prasarana usaha perikanan seperti: dermaga, pelabuhan, pendaratan ikan, percontohan budidaya yang berwasan lingkungan, dll

(8) Peningkatan koordinasi dan kerjasama yang saling menguntungkan antara lembaga atau instansi terkait di wilayah pesisir, melalui pembentukan lembaga koordinasi pengelola wilayah pesisir dan peningkatan posisi tawar perikanan dalam pengamanan ekosistem dan lingkungan pesisir dan laut.

(9) Perluasan pangsa pasar dengan kemitraan melalui: pembinaan pengusaha perikanan, survai kebutuhan pasar global, kerja sama pemasaran, promosi potensi, dan mengemas paket-paket terpadu wisata perikanan.

(10) Pengembangan secara terpadu sektor perikanan dengan sektor lainnya, seperti diversifikasi jenis komoditas dan produk olahan (makanan dan souvenir) dari organisme laut yang dikemas bersama kegiatan pariwisata, dan pengembangan olah raga memancing.

\section{KESIMPULAN DAN SARAN}

Pemanfaatan potensi sumberdaya perikanan tangkap di perairan pantai Kabupaten Padang Pariaman masih berada dibawah MSY (potensi lestari), tetapi telah melebihi jumlah tangkap yang diperbolehkan (JTB), artinya pemanfaatan sumberdaya perikanan di daerah ini sudah melewati titik aman pemanfaatannya.

Secara temporal jenis ikan yang menunjukkan kinerja terbaik selama 5 tahun terakhir di Kabupaten Padang Pariaman adalah ikan lemuru, dan selanjutnya secara berurutan adalah kuwe, tembang, teri, selar, ikan lainnya, tongkol, parang-parang, dan terakhir kembung. Jenis ikan sebagai komoditas unggulan pada 10 prioritas tertinggi secara berurutan adalah ikan tongkol; kuwe; lemuru dan tembang; parang-parang dan ikan lainnya; cakalang; selar; kerapu, kuro, kepiting, dan jenis udang lainnya; merah bambangan dan teri; layur, tuna udang dogol, dan teripang; dan ikan kembung.

Kegiatan perikanan yang dapat dikembangkan di wilayah pesisir Kabupaten Padang Pariaman adalah penangkapan, pengolahan, pemasaran, dan kegiatan budidaya (laut dan payau) yang terbatas. Pengembangan kegiatan perikanan tangkap harus diarahkan pada peningkatan kapasitas armada dan teknologi penangkap untuk dapat mencapai fishing ground yang lebih jauh dalam rangka mengurangi tekanan stok di perairan fishing ground yang ada sekarang. Untuk itu perlu didukung penyediaan sarana dan prasarana tangkap (dermaga, pelabuhan, pabrik es, cold storage, industri perkapalan, dil. ), peningkatan teknologi penanganan dan pengolahan hasil perikanan untuk dapat memenuhi persyaratan ekspor, serta peningkatan aksesibilitas nelayan terhadap sumber permodalan untuk dapat mengembangkan usaha (armada dan teknologi penangkapan).

Pengembangan kegiatan budidaya laut dan payau di Kabupaten Padang Pariaman harus melalui pertimbangan teknis dan ekonomis yang cermat karena luasan lahan potensial yang tidak terlalu besar, sehingga rentan terhadap resiko ekologis dan sulit mencapai skala usaha ekonomis. Pada pelaksanannya, pengembangan kegiatan budidaya ini membutuhkan investasi dan perhatian pemerintah yang lebih besar (seperti: penetapan kawasan budidaya dan tingkat teknologi pemanfaatannya, percontohan dan demplot, pelatihan, dll.), karena sampai saat ini kegiatan ini belum berkembang sama sekali.

Untuk mendapatkan hasil analisis potensi sumberdaya yang lebih akurat, maka metode sampling secara berkala dan sistematis menjadi pilihan terbaik. Melihat data dan informasi yang tersedia di daerah, maka sistem pendataan dan pengumpulan informasi hasil tangkapan, hasil olahan, dan pemasaran hasil perikanan perlu disempurnakan.

Hasil kajian ini menggambarkan bahwa pengkaplingan laut secara kaku (rigid) seperti pemahaman yang salah kaprah tentang UU No. 22 Tahun 1999 tentang Otonomi Daerah sangat tidak menguntungkan dan sulit diatur dengan baik. Hal ini terlihat dari kecilnya luasan cakupan daerah penangkapan dan besarnya jumlah nelayan yang beroperasi di kawasan tertentu menyebabkan produktifitas penangkapan menjadi menurun dan tingginya tekanan terhadap ketersediaan stok.

\section{DAFTAR PUSTAKA}

Anderson, L. G. 1974 The Economics of Fisheries Management. The Johns Hopkins University Press Baltimore and London.

Aziz, K.A. dkk. 1998. Potensi dan Penyebaran Sumberdaya Ikan Laut di Perairan Indonesia Komisi Pengkajian Stok Sumberdaya Ikan Laut. Jakarta.

Azman, S. 2001. Analisis Kebijakan Pengembangan Pariwisata Bahari dalam Rangka Meningkatkan Keragaan Perekonomian Wilayah Kabupaten Padang Pariaman. Thesis. Program Studi Pengelolaan Sumberdaya Pesisir dan Laut Program Pascasarjana Institut Pertanian Bogor. 
Bappeda Kabupaten Padang Pariaman. 1999. Pokokpokok Reformasi Pembangunan Kabupaten Padang Pariaman.

2001a. Penyusunan Rencana Strategis Pengelolaan Sumberdaya Pesisir Kabupaten Padang Pariaman. Laporan Akhir Kerjasama Bappeda Kabupaten Padang Pariaman dengan Pusat Kajian Sumberdaya Pesisir dan Lautan Institut Pertanian Bogor (PKSPL-IPB).

2001b. Penelitian Kondisi Sosial Eknomi, Kependudukan, dan Budaya di Wilayah Pesisir Kabupaten Padang Pariaman. Laporan Akhir Kerjasama Bappeda Kabupaten Padang Pariaman dengan Pusat Penelitian dan Pengembangan Perikanan Universitas Bung Hatta. Padang.

2001c. Penelitian Potensi Budidaya Pantai dan

Laut di Wilayah Pesisir Kabupaten Padang
Pariaman. Ringkasan Laporan Akhir Kerjasama Bappeda Kabupaten Padang Pariaman dengan Pusat Penelitian dan Pengembangan Perikanan Universitas Bung Hatta. Padang.

Bengen, D. G., 1998. Teknik Pengambilan Contoh dan Analisa Data Biofisik Sumberdaya Pesisir. PKSPL IPB. Bogor.

Hermawan, A. 2001. Pengelolaan Sumberdaya Pesisir dan Lautan Kajian Sektor Perikanan Laut dalam Perekonomian Jawa Barat. Thesis Program Studi Pengelolaan Sumberdaya Pesisir dan Laut Program Pascasarjana Institut Pertanian Bogor.

Rangkuti, F. 2000. Analisis SWOT: Teknik Membedah Kasus Bisnis. PT. Gramedia Pustaka Utama

Sparre, P. and Venema, S. C. 1999. Introduksi Pengkajian Stok Ikan Tropis: Buku Manual. FAO dan Puslitbang Perikanan Badan Penelitian dan Pengembangan Pertanian. Jakarta. 
Lampiran 1. Komponen share, proportional shift, differential shift perikanan tangkap Kabupaten Padang Pariaman $1999-2000$

Appendix 1. Component share, proportional shift, differential shif of capture fisheries in Padang Pariaman, 1999-2000

\begin{tabular}{|c|c|c|c|c|}
\hline Jenis Ikan & $\begin{array}{l}\text { Komponen } \\
\text { Share }\end{array}$ & $\begin{array}{c}\text { Proportional } \\
\text { Shift }\end{array}$ & $\begin{array}{l}\text { Differential } \\
\text { Shirft }\end{array}$ & SSA \\
\hline Sebelah/Indian halibut & 0 & 0 & 0 & 0 \\
\hline Peperek/Poni pisces & 0,138800364 & $-0,048783712$ & $-0,401236912$ & $-0,2624365$ \\
\hline Biji Nangka/Goat pisces & -1 & $-1,187584076$ & 0 & -1 \\
\hline Merah Bambangan/Red snapper & $-0,143204539$ & $-0,330788616$ & $-0,209050515$ & $-0,3522551$ \\
\hline Kerapu/Grouper & $-0,455532229$ & $-0,643116305$ & $-0,206009958$ & $-0,6615422$ \\
\hline Kurisi/Thread fire & $-0,625735145$ & $-0,813319221$ & $-0,307598188$ & $-0,9333333$ \\
\hline Cucut/Sharks & 0,034605146 & $-0,15297893$ & $-0,860348641$ & $-0,8257435$ \\
\hline Pari/Sting ray & $-0,09873675$ & $-0,286320827$ & $-0,666280917$ & $-0,7650177$ \\
\hline Layang/Scad & $-0,00152544$ & $-0,189109517$ & $-0,588019073$ & $-0,5895445$ \\
\hline Selar/Trevallies & 0,233313345 & 0,045729269 & 0,512107332 & 0,74542068 \\
\hline Kuwe/Jack trevallies & 0,834028 & 0,646443924 & 2,167515686 & 3,00154369 \\
\hline Tetengkek/Hardtail sead & $-0,14116447$ & $-0,328748546$ & $-0,715758607$ & $-0,8569231$ \\
\hline Kuro/Thread fus & 0,314247069 & 0,126662993 & $-1,033617364$ & $-0,7193703$ \\
\hline Julung-julung/Needle fisheris & $-0,165236052$ & $-0,352820128$ & 0 & 0 \\
\hline Teri/Anchovies & 0,296126978 & 0,108542902 & 0,542455492 & 0,83858247 \\
\hline Japuh/Rainbow sardine & 0,087267312 & $-0,100316764$ & $-0,828540847$ & $-0,7412735$ \\
\hline Tembang/Fringscale sardinella & 0,676072059 & 0,488487983 & 1,236083904 & 1,91215596 \\
\hline Lemuru/Indian oil sardinella & 0,804738921 & 0,617154844 & 6,96187096 & 7,76660988 \\
\hline Parang-parang/Wolf herings & 0,327425707 & 0,139841631 & $-0,12717925$ & 0,20024646 \\
\hline Kembung//ndian mackerel & $-0,040564738$ & $-0,228148814$ & 0,102613242 & 0,0620485 \\
\hline Tenggiri/Narrow bared & $-0,357766143$ & $-0,545350219$ & $-0,399418182$ & $-0,7571843$ \\
\hline Layur/Hair tail & $-0,459918653$ & $-0,647502729$ & $-0,414679664$ & $-0,8745983$ \\
\hline TunalTunas & $-0,096016069$ & $-0,283600145$ & $-0,402634438$ & $-0,4986505$ \\
\hline Cakalang/Skipjack tuna & 0,245218948 & 0,057634871 & $-0,293709476$ & $-0,0484905$ \\
\hline Tongkol/Eastern & 0,326573921 & 0,138989845 & 0,025688346 & 0,35226227 \\
\hline Ikan Lainnyal Other fisher & 0,735853213 & 0,548269137 & $-0,255594211$ & 0,480259 \\
\hline Rajungan/Swim crabs & 0 & 0 & 0 & 0 \\
\hline Kepiting/crabs & 0 & 0 & 0 & 0 \\
\hline Udang Dogol/Metapenaeus shrimp & 0,568855535 & 0,176968638 & 0 & 0 \\
\hline Jenis Udang Lainnya/other shrimp & $-0,359158356$ & $-0,751045253$ & $-0,517394439$ & $-0,8765528$ \\
\hline Teripang/Sea cucumber & -1 & $-0,899703264$ & 0 & -1 \\
\hline
\end{tabular}


